\title{
EFFECT OF FIRM GROWTH AND FIRM SIZE ON COMPANY VALUE WITH EARNING PER SHARE AS MODERATION
}

\author{
Retno Fuji Oktaviani \\ Universitas Budi Luhur \\ retno.fujioktaviani@budiluhur.ac.id
}

\begin{abstract}
This study aims to analyze the effect of Firm Growth and Firm Size on Firm Value with Earning Per Share as Moderation (Empirical Study Plastics and Packaging Public Companies on the Indonesian Stock Exchange for the Period of 2014 - 2018). The population in this study were 14 companies, then the researchers used purposive sampling technique so that the research sample was obtained as many as 12 companies. The analysis used is multiple linear regression with moderation. The author uses statistical tools, namely SPSS version 24.0 and Microsoft Excel as data tabulation calculations. The results of the study found that firm growth has an negative influence on firm value, firm size has no effect on firm value, while EPS is proven to moderate the effect of firm size and firm growth on firm value.
\end{abstract}

Keywords: firm growth, firm size, earnings per share, firm value

\section{INTRODUCTION}

Until now, the plastic packaging industry still has an important role in the supply chain for other strategic sectors such as the food and beverage industry, pharmaceuticals, cosmetics, and electronics. Based on the National Industrial Development Master Plan (RIPIN), the Ministry of Industry has designated the plastic industry as a priority sector for development in 2015-2019. The Ministry of Industry noted that the number of plastic industries to date has reached 925 companies that produce various kinds of plastic products. This sector employs a workforce of 37,327 people and has a total production of 4.68 million tons. Therefore, the Director General of Chemical, Textile and Multifarious Industries (IKTA) Achmad Sigit Dwiwahjono said that the Ministry of Industry continues to strive to improve the competitiveness of the plastics industry through various strategic policies, especially facing the ASEAN Economic Community (MEA) and world free trade (Luluk, 2019). Investment can be defined as saving money to be expected to get a higher return than deposit interest with the aim of fulfilling what is wanted within a predetermined period of time according to capital capacity. Investment has two sides, namely return and risk. The value of the company is very important, because if the value of the company increases, the prosperity of the shareholders will also 
increase. If the shareholder gets a profit on every share invested from the investment, it can also benefit the company. The profits obtained can come from several sources, namely the company's net income and the increase in share prices on the Stock Exchange. The higher the stock price, the higher the company value. With better corporate value, potential investors will see the company as having more value. Price to Book Value is the ratio of the stock market price to the book value of the company, where the amount of invested capital is shown by the company's ability to create relative value.

Firm growth measures how much the company's ability to maintain its position in the industry and in general economic development. This growth ratio is seen from various aspects of sales, EAT, earnings per share, dividends per share, and market price per share.

Firm size is a size, scale or variable that describes the size of the company based

\section{LITERATURE REVIEW}

According to Harmono (2017), the goal of company management is to maximize the value of the shareholders' wealth. Firm value can be measured through the value of the stock price in the market based on the formation of the company's stock price in the market, which is a reflection of the public's assessment of the company's real performance.

According to Pioh, et al (2018). Company value is one of the most important things and must be considered by investors in making investment decisions in a company. A high company value is the desire of company owners, because a high value shows that the shareholder's prosperity is also high. This is the desire of investors to invest their funds in a company. Firm value can not on several conditions, such as total assets, log size, market value, shares, total sales, total revenue, and total capital. Large companies are considered to have less risk, so this can affect firm value (PBV).

Earning Per Share (EPS) represents the amount of money that will be received by the shareholders for each share they own when sharing the profits from the shares that come at the end of the year. The figures shown from EPS are often published regarding the performance of companies that sell their shares to the wider community (going public) because investors and potential investors are of the view that EPS contains important information for making predictions about the amount of dividends per share and the level of stock prices in the future, and EPS is also relevant for assessing the effectiveness of management and dividend payout policies.

only be described in the share price of a company. To measure the high value of the company can be done in various ways, and one measuring tool that can be used is the Price Book Value.

$$
\text { PBV }=\frac{\text { Market price per share }}{\text { Book value per share }}
$$

Source: Murhadi (2015: 66)

Firm Growth According to Kasmir (2015), growth ratio is a ratio that describes a company's ability to maintain its economic position amidst economic growth and its business sector. The growth ratios analyzed are sales growth, net income, earnings per share and dividends per share. The growth of the company or firm growth can be formulated as follows:

* Corresponding author's e-mail: retno.fujioktaviani@budiluhur.ac.id http://openjournal.unpam.ac.id/index.php/EAJ 


$$
F G=\frac{\text { Total Asset }_{t}-\text { Total Asset }_{t-1}}{\text { Total Asset }_{t-1}}
$$

Source: Putra and RM (2019: 2465)

According to Mulyawan (2015), a large company size makes it easier for companies to access the capital market. This allows the company to easily get additional funds for its operations. Company size can be interpreted as the size or size of the assets owned by the company.

According to Sartono (2015), large, well-established companies will find it easier to obtain capital in the capital market compared to small companies. Because the ease of access means large companies have great flexibility as well. Empirical evidence says that the scale of the company is positively related to the ratio of debt to book value of equity. The formula used by researchers to calculate the size of the company or firm size:

$$
\text { Firm Size }=\text { LN (Total Asset })
$$

Source: Sartono, et al (2015: 49)

According to Kasmir (2015), Earning Per Share is a ratio to measure the success of management in achieving benefits for shareholders. A low ratio means that management has not succeeded in satisfying shareholders, on the other hand, a high ratio indicates the prosperity of shareholders. The formulas used in this research are:

$$
\text { EPS }=\frac{\text { net profit }}{\text { Number of share }}
$$

Source: Kasmir (2015: 150)

\section{RESEARCH METHOD}

\subsection{Operational Definitions of}

\section{Variables}

\section{Dependent Variable}

Firm value is proxied using Price to Book Value (PBV). Because PBV has been widely used for making investment decisions. In addition, there are several advantages of PBV such as book value which is a stable and simple measure that can be compared to market prices, and PBV can also be compared between similar companies to show signs of expensive or cheap shares (Murhadi, 2015).

\section{Independent Variable}

Firm Growthis a company with a high growth rate indicating that the company's ability to manage its resources has a high advantage. If the company's growth assets increase, investors will be interested in buying shares. This means that the demand for the company's shares will also increase. Thus this will cause the company value to increase (Putra and RM, 2019).

Firm Size is the size of the company can be described as the size of a company, both seen from the number of assets and from the level of sales, and will greatly affect the amount of working capital (Halim and Sarwoko, 2016).

\section{Variable Moderating}

Earning Per Share measures the amount of net income earned per measured share. A low ratio means that management has not succeeded in satisfying shareholders, on the other hand, a high ratio indicates the prosperity of shareholders (Kasmir, 2015).

\subsection{Sample Collection Techniques}

The sampling technique used in this study was purposive sampling. Purposive sampling is a sampling technique with

* Corresponding author's e-mail: retno.fujioktaviani@budiluhur.ac.id http://openjournal.unpam.ac.id/index.php/EAJ 
certain considerations. The data used is 35 because this study uses LN transformation so that eliminates negative values and this study uses sptepwise method in analyze SPSS.

Table 1. Sample Criteria

\begin{tabular}{|l|l|c|}
\hline No. & $\begin{array}{l}\text { Sample Selection } \\
\text { Criteria }\end{array}$ & total \\
\hline 1. & $\begin{array}{l}\text { Plastic and } \\
\text { packaging companies } \\
\text { listed on the } \\
\text { Indonesian stock } \\
\text { exchange for the } \\
\text { period 2014 - 2018. }\end{array}$ & 14 \\
\hline & $\begin{array}{l}\text { Plastic and } \\
\text { packaging companies } \\
\text { that did not publish } \\
\text { complete financial } \\
\text { reports during the } \\
\text { study period. }\end{array}$ & \\
\hline 3. & $\begin{array}{l}\text { The number of } \\
\text { companies that meet } \\
\text { the sample criteria. }\end{array}$ & 12 \\
\hline
\end{tabular}

\subsection{Data Analysis Techniques}

This study uses multiple linear regression analysis with moderating variables. The statistical analysis tool used is the Statistical Package for the Social Sciences Version 24.0. The tests carried out include the classical assumption test which consists of normality test, multicollinearity test, heteroscedasticity test, autocorrelation test. Then performed a hypothesis test consisting of determination test, correlation test, model feasibility test and $t$ test. Based on the results of hypothesis testing, multiple linear regression equations can be obtained.

\section{RESULTS AND DISCUSSION}

\subsection{Results}

1. Descriptive
Results Descriptive statistics can provide an overview of each variable regarding the average value (Mean), Standard Deviation, and the number of samples studied.

Table 2. Variable Descriptive Statistics

\begin{tabular}{|l|r|r|r|}
\hline & $\mathrm{N}$ & \multicolumn{1}{|c|}{ Minimum } & Maximum \\
\hline Firm growth & 35 & -.562 & 2,576 \\
\hline Firm size & 35 & 26,333 & 29,073 \\
$\begin{array}{l}\text { Earning per } \\
\text { share }\end{array}$ & 35 & $-182,087$ & 2923,970 \\
$\begin{array}{l}\text { Price book } \\
\text { value }\end{array}$ & 35 & .220 & 4,087 \\
$\begin{array}{l}\text { Valid N } \\
\text { (listwise) }\end{array}$ & 35 & & \\
Source: SPSS 23 Output Backward Method
\end{tabular}

\section{Classic Assumption Test}

a. Normality Test

Table 3. Kolmogorov Smirnov Test

\begin{tabular}{|c|c|}
\hline & $\begin{array}{l}\text { Unstandardized } \\
\text { Residual }\end{array}$ \\
\hline $\mathrm{N}$ & 35 \\
\hline Statistical Test & .114 \\
\hline $\begin{array}{c}\text { Asymp. Sig. (2- } \\
\text { tailed) }\end{array}$ & $.200 \mathrm{c}, \mathrm{d}$ \\
\hline
\end{tabular}

a. Test distribution is Normal.

b. Calculated from data.

c. Lilliefors Significance Correction.

d. This is a lower bound of the true significance.

Based on table 3. One Sample Kolmogorov Smirnov shows that the Asymp. Sig. (2-tailed) is 0.200. The significance value is greater than 0.05 $(0.200>0.05)$ which indicates that the data is normally distributed and this data is suitable for use for research.

\section{b. Multicolinearity Test}

* Corresponding author's e-mail: retno.fujioktaviani@budiluhur.ac.id http://openjournal.unpam.ac.id/index.php/EAJ 


Table 4. Multycolinearity Test
\begin{tabular}{|c|l|l|r|}
\hline Model & \multicolumn{2}{|c|}{$\begin{array}{c}\text { Collinearity } \\
\text { Statistics }\end{array}$} \\
\hline \multirow{3}{*}{2} & & Tolerance & VIF \\
& (Constant) & & \\
\cline { 2 - 4 } & FG & .964 & 1,037 \\
\cline { 2 - 4 } & FG_EPS & .798 & 1,253 \\
\cline { 2 - 4 } & FS_EPS & .822 & 1,217 \\
\hline
\end{tabular}

Based on table 4, it can be seen that the Tolerance value of each independent variable is greater than 0.1 and has a VIF (Variance Inflation Factor) value of less than 10 . So that the independent variable does not have multicollinearity problems.

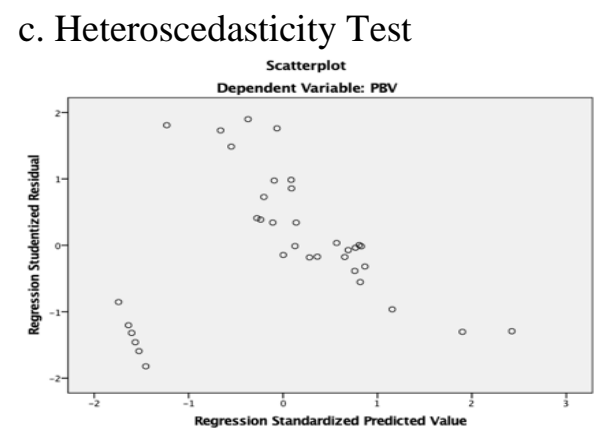

Figure 1. Scatterplot

Based on the results of the output above, it can be seen that the dots spread randomly and do not form a pattern, and the points spread below and above the number 0 on the $\mathrm{Y}$ axis. So it can be concluded that there is no heteroscedasticity in this regression model.

\section{d. Autocorrelation Test}

\begin{tabular}{|c|c|} 
Table 5. Durbin Watson \\
Model & $\begin{array}{r}\text { Durbin- } \\
\text { Watson }\end{array}$ \\
\hline 2 & 2.013 \\
\hline
\end{tabular}

Based on table 5. it can be concluded that the value of Durbin Watson (DW) is 2.013. whereas from the DW table with a significant 0.05 and $\mathrm{n}=35$ and $\mathrm{k}=4$, the dL value is 1.2078 and the $\mathrm{dU}$ is 1.7277 , so that the DW is between $(\mathrm{dL})$ and $(\mathrm{dU})$ or in the form of a notationdU $<\mathrm{DW}<4$ dU. So it can be said that there is no autocorrelation in the regression model.

2. Correlation Test

Table 6. Correlation

\begin{tabular}{|c|c|c|}
\hline & & PBV \\
\hline \multirow[t]{5}{*}{$\begin{array}{l}\text { Pearson } \\
\text { Correlation }\end{array}$} & $\begin{array}{l}\text { Price book } \\
\text { value }\end{array}$ & 1,000 \\
\hline & Firm growth & -.290 \\
\hline & Firm size & -.014 \\
\hline & FG_EPS & .944 \\
\hline & FS_EPS & .269 \\
\hline \multirow[t]{5}{*}{$\begin{array}{l}\text { Sig. } \\
\text { tailed) }\end{array}$} & $\begin{array}{l}\text { Price book } \\
\text { value }\end{array}$ & \\
\hline & Firm growth & .045 \\
\hline & Firm size & .469 \\
\hline & FG_EPS & .000 \\
\hline & FS_EPS & .059 \\
\hline
\end{tabular}

Based on table 6 , the results of the correlation coefficient test show that the results of the relationship with each other for each variable can be concluded as follows:

At the Sig. (2-tailed) firm growth is $0.045(0.045<0.05)$, this shows that there is a significant relationship between firm growth and Price to Book Value. The magnitude of the correlation coefficient is -0.290 , which means that the Company Growth variable with Price to Book Value has low and negative correlation.

At the Sig. (2-tailed) firm size is 0.469 $(0.469>0.05)$, this shows that there is no significant relationship between firm size and Price to Book Value.

* Corresponding author's e-mail: retno.fujioktaviani@budiluhur.ac.id http://openjournal.unpam.ac.id/index.php/EAJ 
At the Sig. (2-tailed) EPS moderation with firm growth is $0.000(0.000<0.05)$, this shows that there is a significant relationship between EPS moderation and firm growth on Price to Book Value. The magnitude of the correlation coefficient is 0.944 , which means that the EPS moderating variable with firm growth on Price to Book Value has a very strong and positive correlation.

At the Sig. (2-tailed) EPS moderation with firm size is $0.059(0.059>0.05)$, this shows that there is no significant relationship between EPS moderation and firm size on Price to Book Value.

\section{Determination Test}

Table 7. Determination test

\begin{tabular}{|c|c|c|c|}
\hline Model & $\mathrm{R}$ & $\begin{array}{c}\mathrm{R} \\
\text { Square }\end{array}$ & $\begin{array}{l}\text { Adjusted } \\
\text { Square }\end{array}$ \\
\hline 1 & $.961 \mathrm{a}$ & .924 & .914 \\
\hline 2 & $.961 \mathrm{~b}$ & .924 & .917 \\
\hline
\end{tabular}

Based on table 7, it can be seen that the value of $\mathrm{R}^{2}$ (Adjusted R Square) is 0.917 or $91.7 \%$, which means firm growth, EPS moderation with firm growth and EPS moderation with firm size can affect the Price to Book Value of $91.7 \%$, the rest is equal to $8.3 \%$ is determined by other variables outside the research.

\section{Goodness of Fit Test}

Table 8. Anova

\begin{tabular}{|r|r|r|r|r|}
\hline \multirow{2}{*}{2} & & df & F & Sig. \\
\cline { 1 - 3 } 2 & Regression & 3 & 125,992 & $.000 \mathrm{c}$ \\
\cline { 2 - 5 } & Residual & 31 & & \\
\cline { 2 - 4 } & Total & 34 & & \\
\hline
\end{tabular}

Based on table 8 , the results of the Model Feasibility Test test show that the significant value is $0.000(0.000<0.05)$, which means that the regression model is feasible to use.
5. The $t$ test

\begin{tabular}{|c|c|c|c|c|c|}
\hline \multirow{2}{*}{\multicolumn{2}{|c|}{ Model }} & \multicolumn{2}{|c|}{$\begin{array}{l}\text { Unstandardized } \\
\text { Coefficients }\end{array}$} & \multirow[b]{2}{*}{$t$} & \multirow[b]{2}{*}{ Sig. } \\
\hline & & B & $\begin{array}{l}\text { Std. } \\
\text { Error }\end{array}$ & & \\
\hline \multirow[t]{4}{*}{2} & (Constant) & .822 & .315 & 2,607 & .014 \\
\hline & $\begin{array}{l}\text { Firm } \\
\text { growth }\end{array}$ & -242 & .099 & $-2,455$ & .020 \\
\hline & FG_EPS & 1,511 & .085 & 17,707 & .000 \\
\hline & FS_EPS & -.509 & .203 & $-2,510$ & .018 \\
\hline
\end{tabular}

Based on table 9, the results of the $t$ statistical analysis test can be explained as follows:

Effect of Firm Growth on Firm Value. The results showed $t$ count of $-2.455<-$ 2.045 with a significance value of 0.020 $(0.020<0.05)$, it can be concluded that $\mathrm{H} 0$ is rejected and $\mathrm{H} 1$ is accepted, which means that Firm Growth has a significant effect on Firm Value (PBV).

The Effect of EPS Moderation with Firm Growth on Firm Value. The results showed t count of 17.707> 2.045 with a significance value of $0.000(0.00<0.05)$, it can be concluded that $\mathrm{H} 0$ is rejected and $\mathrm{H} 3$ is accepted, which means that Earning Per Share moderates the effect of Firm Growth on firm value (PBV).

The Effect of EPS Moderation with Firm Size on Firm Value. The results showed $t$ count of $-2.510<-2.045$ with a significance value of $0.018 \quad(0.018$ $<0.05$ ), it can be concluded that $\mathrm{HO}$ is rejected and $\mathrm{H} 4$ is accepted, which means that Earning Per Share moderates the effect of Firm Size on firm value (PBV).

6. Multiple Linear Regression Equation

Based on table 9, it can be seen that the regression equation is as follows:

* Corresponding author's e-mail: retno.fujioktaviani@budiluhur.ac.id http://openjournal.unpam.ac.id/index.php/EAJ 
$P B V=0,822-0,242 F G+1,511 E P S_{F G}-0,509 E P S_{F G}$

Table 10. Excluded variable

\begin{tabular}{|r|r|r|r|r|}
\hline Model & Beta \\
& In & $\mathrm{t}$ & Sig. \\
\hline 2 & FS & - & - & \\
& & $.006^{\mathrm{b}}$ & .119 & .906 \\
\hline
\end{tabular}

Effect of firm size on PBV the result showed significant value $0.906>0.05$ it can be concluded that $\mathrm{H} 1$ is rejected and HO is accepted, which means that Firm size has a not significant effect on Firm Value (PBV).

\section{CONCLUSION}

Based on the results of the research that has been done and described above, the following results are obtained:

\section{Effect of Firm Growth on Firm Value}

Based on the results of this study firm growth has a negative effect on Firm Value in the plastic and packaging subsector companies during the 2014-2018 period. This explains that if firm growth increases, then Firm Value will decrease. This means that an increase in total assets does not increase the desire of investors to buy shares in the company, because an increase in total assets will have a negative impact on the company's shares. The ratio is a ratio that describes a company's ability to maintain its economic position amidst economic growth and its business sector (Kasmir, 2017).

Effect of Firm Size to Company Value Based on the results of this study, firm size has no effect on firm value in the plastic and packaging sub-sector companies during the 2014-2018 period. It is explained that the size of the firm size has no effect on Firm Value. This means that the size of the company as measured by total assets is not a reference for investors' interest in buying company shares. Company size describes the size of the company which is determined by several things, including total sales, total assets and average sales of the company. Large and well-established companies usually have easy access to external funding, both capital and debt markets, so that companies are able to pay large dividends to shareholders (Hanif and Bustamam, 2017).

\section{The Effect of EPS Moderation with Firm Growth on Firm Value}

Based on the results of this study, EPS can moderate the effect of firm growth on Firm Value in the plastic and packaging sub-sector companies during the 20142018 period. This explains that EPS can be used to measure the success of management in achieving benefits for shareholders. Low EPS means that management has not succeeded in satisfying the shareholders, and vice versa, high EPS will increase the welfare of shareholders or will obtain a high rate of return on shares. an increase in total assets does not mean that investors will want to buy shares in the company, because an increase in total assets will have a negative impact on the company's shares.

\footnotetext{
Effect of EPS Moderation with Firm Size to Company Value

Based on the results of this study, EPS can moderate firm size which has an influence on Firm Value in the plastic and packaging sub-sector companies during the 2014-2018 period. It is explained that Earning Per Share is one of the interesting things for investors to decide on investing their funds for the company. If the profit generated by each share in
}

* Corresponding author's e-mail: retno.fujioktaviani@budiluhur.ac.id http://openjournal.unpam.ac.id/index.php/EAJ 
circulation is so good, then the welfare of shareholders can be guaranteed by looking at dividend payments at the end of each year the company operates. The large company size makes it easier for the company to access the capital market. This allows the company to easily obtain

\section{REFERENCES}

Annisa, R. and Chabachib, M. (2017). Analysis of the Effect of Current Ratio (CR), Debt to Equity Ratio (DER), Return on Assets (ROA) on Price to Book Value, with Dividend Payout Ratio as an Intervening Variable (case study on Manufacturing Industrial Companies listed on the IDX 2011-2014 period ). Diponegoro Journal of Management, 6 (1), 1 15.

Dewi. (2018). Financial management. Jakarta: Mitra Wacana Media.

Fahmi, Irham. (2017). Financial Statement Analysis. Bandung: Alfabeta.

Fahmi, Irham. (2018). Introduction to Financial Management. Bandung: Alfabeta.

Ghozali, Imam. (2016). Multivariate Analysis Application with SPSS Program. 23 Ed. 8. Semarang: Diponegoro University Publishing Agency.

Harmono. (2017). Financial Management Based on Balanced Scorecard Approaches to Theory, Cases, and Business Research. Second printing. Jakarta: PT Bumi Aksara.

Hery. (2016). Financial Statement Analysis. Jakarta: PT Grasindo.

Hikmawanti, Fenti. (2017). Research methodology. 1st printing. Jakarta: Rajagrafindo Persada. additional funds for its operations. Company size can be interpreted as the size or size of the assets owned by the company.

Hizkia T. Pioh, Parengkuan Tommy, Jantje L. Sepang. 2018. The Effect of Debt to Equity Ratio,Earning Per Share and Return on Assets Against Company Value in the Food and Beverages Sub-Sector in the Indonesia Stock Exchange. Faculty of Economics and Business, Department of Management, Sam Ratulangi University. EMBA Journal Vol. 6 No. 4 September 2018, p. 3018 3027.

Luluk Innafisah, Afifuddin, M. Cholid Mawardi, 2019. The Effect of Earning Per Share (EPS), Price Earning Ratio (PER) and Dividend Payout Ratio (DPR) on the Value of Property and Real Estate Companies Listed on the Indonesia Stock Exchange (BEI) for the 2014-2017 period. Faculty of Economics and Business, Islamic University of Malang, $E$ JRA Vol. 08 No. 07, pg. 37-52.

Kasmir. (2015). Analysis of Financial Statements. First Edition, Eighth Edition. Jakarta: Rajawali Press.

Mudjijah, S., Khalid, Z., and Astuti, DAS (2019). The Effect of Financial Performance and Capital Structure on Firm Value as Moderated by the Variable of Firm Size. Journal of Accounting and Finance, 8 (1), 41 - 56.

Mulyawan, Setia. (2015). Financial management. Bandung: Faithful Library.

* Corresponding author's e-mail: retno.fujioktaviani@budiluhur.ac.id http://openjournal.unpam.ac.id/index.php/EAJ 
EAJ (Economics and Accounting Journal) - Vol. 3, No. 3, Sept 2020 -Oktaviani

Murhadi, Werner R. (2015). Analysis of Projected Financial Statements and Stock Valuation. Jakarta: Four Salemba.

Murhadi, Werner R. (2015). Analysis of Projected Financial Statements and Stock Valuation. Jakarta: Four Salemba.

Pioh, HT, Tommy, P., and Sepang, JL (2018). The Effect of Debt to Equity Ratio, Earning Per Share, and Return on Assets on Firm Value in the Food and Beverages Sub-Sector in the Indonesia Stock Exchange. Journal of EMBA Accounting, 6 (4), 3018 - 3027.

Priyatno, Dwi. (2017). Practical Guide to Processing Data Using SPSS. Yogyakarta: CV Andi Offset.

Putra, TA and RM, KM (2019). The Influence of Company Growth on Firm Value with CSR Disclosure as a Moderating Variable. $E$ -
Journal of Udayana University Accounting, 26 (3), 2453 - 2478.

Santoso, Singgih. (2018). Advanced Parametric Statistics. Jakarta: PT Elex Media Komputindo.

Subramanyam. (2017). Financial Statement Analysis. edition 11. Jakarta: Salemba four.

Sudaryono. (2017). Research methodology. Jakarta: PT. Rajagrafindo Persada.

Sugiyono. (2017). Quantitative Research Methods, Qualitative, and $R \& D$. Bandung: Alfabeta

Sugiyono. (2018). Quantitative Research Methods. Bandung: Alfabeta.

Sujarweni, V. Wiratna. (2014). SPSS For Research. Yogyakarta: Library

Surjaweni, V. Wiratna. (2015). Statiska for research. Yogyakarta: New Library Press.

Sutrisno. (2017). Financial Management Theory Concepts \& Applications. Yogyakarta: Yogyakarta Econisia.

* Corresponding author's e-mail: retno.fujioktaviani@budiluhur.ac.id http://openjournal.unpam.ac.id/index.php/EAJ 